\title{
Calcemia and Inflammatory Markers in Early-Onset Neonatal Infection
}

\author{
Štěpán Kutílek¹,*, Martina Vracovská1, Kamila Pečenková1, Hana Brožíkováa , Richard Pikner², \\ Zlatka Fejfarková
}

\begin{abstract}
Introduction: Ionised hypocalcemia $\left(\mathrm{S}-\mathrm{Ca}^{2+}\right)$ has been repeatedly observed in neonates with sepsis. Our aim was to evaluate total calcemia (S-Ca) and its relationship to laboratory markers of infection.

Methods: We retrospectively evaluated total calcemia (S-Ca) and its relationship to laboratory markers of sepsis/infection (serum levels of C-reactive protein-S-CRP and procalcitonin-S-PCT) in 29 full-term neonates with early-onset neonatal infection hospitalized at our neonatology ward between 2012 and 2016. The control group consisted of 705 neonates without infection.

Results: In neonates with early-onset infection, the S-Ca on day 1,2 and 3 was significantly lower $(p<0.0001 ; p<0.0001 ; p=0.05$ versus controls) same as the pooled S- $\mathrm{Ca}(p<0.0001$ versus controls). There was a weak negative correlation between pooled S-Ca and S-PCT, or pooled S-Ca and S-CRP $(r=-0.22, p=0.06 ; r=-0.19, p=0.09)$.

Conclusion: S-Ca was decreased in neonates with early-onset infection and did show a slight tendency to inverse correlation with S-CRP and S-PCT. Pediatricians must be aware of the fact that a drop in total S-Ca should alert their attention to the risk of neonatal infection, and, likewise, that the children with neonatal infection are at a higher risk of hypocalcemia with all its consequences.
\end{abstract}

\section{KEYWORDS}

calcium; early-onset neonatal infection; neonate

\section{AUTHOR AFFILIATIONS}

${ }^{1}$ Department of Pediatrics, Klatovy Hospital, Klatovy, Czech Republic

2 Department of Clinical Biochemistry, Klatovy Hospital, Klatovy, Czech Republic

* Correspondening author: Department of Pediatrics, Klatovy Hospital, Klatovy Czech Republic; e-mail: kutilek@nemkt.cz 


\section{INTRODUCTION}

Neonatal hypocalcemia can occur in premature or hypotrophic children, other risk factors include infection, maternal diabetes, perinatal asphyxia, low calcium intake, maternal hyperparathyroidism, phosphate overload, transient or primary hypoparathyroidism, hypomagnesemia, hepatopathy or end organ resistance to the biological actions of parathyroid hormone (PTH) (1-7). Hypocalcemia, in particular low level of serum ionized calcium $\left(\mathrm{S}-\mathrm{Ca}^{2+}\right)$, has been repeatedly reported in neonates with sepsis (1-7).

Newborns with hypocalcemia are either asymptomatic, or may present with hypotonia, apnea, poor feeding, jitteriness, seizures, cardiac failure. Signs of hypocalcemia rarely occur unless S-Ca drops below $1.75 \mathrm{mmol} / \mathrm{l}$ (7).

The pathogenesis of hypocalcemia in sepsis is explained by the increased secretion of procalcitonin, the precursor of calcitonin, with consequent hypocalcemic effects $(8,9)$.

The upregulation of calcium-sensing receptor (CaSR) by cytokines, in particular tumor-necrosis factor alpha (TNF-alpha), interleukin-1 beta (IL-1beta) and IL-6 may also play a significant role in the pathogenesis of hypocalcemia in sepsis. The upregulation of CaSR results in decreased serum PTH and 1,25-dihydroxyvitamin D and calcium levels (10-11).

Administration of aminoglycosides, in particular gentamicin, to neonates, is also associated with a drop in calcemia (12-13). This could be explained by the fact that aminoglycoside antibiotics are CaSR agonists (14-15).

Ionised hypocalcemia is considered a negative prognostic factor in the neonatal sepsis, together with calcitoninemia and serum levels of PTH $(5,6,8)$. Furthermore, ionised hypocalcemia is associated with organ dysfunction in children admitted to intensive care unit (4).

Our aim was to retrospectively evaluate total calcemia (S-Ca) and its relationship to laboratory markers of sepsis/infection (serum levels of C-reactive protein - S-CRP and procalcitonin - S-PCT) in neonates.

\section{PATIENTS, MATERIALS, METHODS}

Between the years 2012 and 2016, 3441 neonates were hospitalized at our neonatology ward. Total calcemia was assessed in 988 samples drawn from 828 babies. Out of those, neonatal infection was diagnosed in 29 full-term children (Table 1), based on Töllner scores (abnormal skin color, prolonged capillary refill time, muscular hypotonia, bradycardia, apnea, respiratory distress, hepatomegaly, gastrointestinal symptoms, number of leukocytes, increased number of immature neutrophils, thrombocytopenia, metabolic acidosis) $>5$ points (16) and S-CRP or S-PCT elevation. All 29 children were treated by intravenously administered gentamicin and ampicillin for seven days, with a favorable outcome. The control assessments of inflammatory markers and S-Ca were based on the clinical situation of the patients The blood samples were collected on days 1, 2 and 3 of the infection, however all three parameters (S-Ca, CRP, PCT) were not always assessed in each obtained sample (vide infra).
Tab. 1 Patient data.

\begin{tabular}{|l|l|}
\hline Total number of patients & 29 \\
\hline Boys : girls ratio & $16: 13$ \\
\hline Mean and median gestational age \pm SD (weeks) & $39.4 ; 39.5 \pm 1.9$ \\
\hline Mean and median birthweight \pm SD (grams) & $3310 ; 3355 \pm 537$ \\
\hline Mean and median body length \pm SD (cm) & $50 ; 50 \pm 2.5$ \\
\hline $\begin{array}{l}\text { Mean and median age at onset of infection } \pm \\
\text { SD (days) }\end{array}$ & $1.6 ; 1.0 \pm 1.4$ \\
\hline $\begin{array}{l}\text { Number of blood draws in children with ear- } \\
\text { ly-onset infection within the first three days of } \\
\text { illness }\end{array}$ & 87 \\
\hline $\begin{array}{l}\text { Mean and median age at the time of blood } \\
\text { draws } \pm \text { SD (days) }\end{array}$ & $1.8 ; 2.0 \pm 0.9$ \\
\hline Control group - total number & 705 \\
\hline \begin{tabular}{l} 
Boys : girls ratio \\
\hline Total number of blood draws in control group
\end{tabular} & 800 \\
\hline $\begin{array}{l}\text { Mean and median age at the time of blood } \\
\text { draws } \pm \text { SD (days) }\end{array}$ & $2.2 ; 2.0 \pm 1.8$ \\
\hline
\end{tabular}

SD: standard deviation

Total calcemia (kit CalciumC - Abbott, method Arsenazo III; analyser Architect) was assessed on day 1 of the infection in 29 patients $(\mathrm{n}=29 ; 100 \%)$; on day $2(\mathrm{n}=14$; $48.3 \%)$ and on day $3(n=17 ; 58.6 \%)$.

C-reactive protein (kit CRP Vario, method turbidimetry/imunoturbidimetry; analyser Architect) was assessed on day 1 of the infection $(n=29 ; 100 \%)$, on day $2(n=27$; $93.1 \%)$ and on day $3(\mathrm{n}=24 ; 82.8 \%)$.

Procalcitonin (kit Liaison Brahms PCT II GEN, chemiluminiscence analysis CLIA, analyser Liaison XL) was assessed on day 1 of the infection ( $\mathrm{n}=19 ; 65.5 \%)$, on day 2 ( $\mathrm{n}=21 ; 72.4 \%)$ and on day $3(\mathrm{n}=15 ; 51.7 \%)$.

As mentioned above, out of 828 neonates, where S-Ca was assessed, 29 were diagnosed with early-onset infection. Therefore, 799 neonates ( 424 boys and 375 girls) were considered as free of infection/sepsis. Due to the fact, that all 29 patients suffered from early-onset infection within the first three days of life and we evaluated their biochemical data (S-Ca, CRP, PCT) in the following three days, the age-matched control group was selected to include S-Ca results from full-term neonates under 6 days of age ( $\mathrm{n}=705 ; 413$ boys and 292 girls) (Table 1 ). The reasons for blood draws and biochemical assessments (including $\mathrm{S}-\mathrm{Ca}$ ) in these children were: hypotonia, tachypnea, jaundice, body temperature changes, vomiting, maternal risk factors (diabetes, hypertension, nicotinism/drug addiction). None of the controls presented with infection or severe metabolic disorder.

Unpaired t-test and Pearson's correlation were used for statistical analysis (SigmaPlot software). The values were expressed as mean and median \pm standard deviation (SD).

\section{RESULTS}

The mean value of S-Ca in 799 children without infection was $2.36 \pm 0.19 \mathrm{mmol} / \mathrm{l}$. The mean value of $\mathrm{S}-\mathrm{Ca}$ in 705 children (considered as a control group) was 2.38 
Tab. 2 Correlations between S-Ca and S-CRP and S-PCT, respectively.

\begin{tabular}{|l|l|l|l|l|l|l|}
\hline Parameter & $\begin{array}{l}\text { S-CRP } \\
\text { day } \mathbf{1}\end{array}$ & $\begin{array}{l}\text { S-CRP } \\
\text { day } \mathbf{2}\end{array}$ & $\begin{array}{l}\text { S-CRP } \\
\text { day 3 }\end{array}$ & $\begin{array}{l}\text { S-PCT } \\
\text { day 1 }\end{array}$ & $\begin{array}{l}\text { S-PCT } \\
\text { day 2 }\end{array}$ & $\begin{array}{l}\text { S-PCT } \\
\text { day 3 }\end{array}$ \\
\hline S-Ca day 1 & -0.07 & -0.1 & -0.1 & -0.08 & -0.09 & -0.1 \\
\hline S-Ca day 2 & -0.08 & -0.1 & -0.08 & -0.08 & -0.1 & -0.09 \\
\hline S-Ca day 3 & -0.1 & 0.03 & -0.08 & -0.09 & -0.08 & -0.09 \\
\hline
\end{tabular}

$\pm 0.21 \mathrm{mmol} / \mathrm{l}$. In neonates with infection, the mean value of S-Ca on day 1 was $2.16 \pm 0.30 \mathrm{mmol} / \mathrm{l}$, median $2.13 \mathrm{mmol} / \mathrm{l} ; 2.12 \pm 0.18 \mathrm{mmol} / \mathrm{l}$, median $2.03 \mathrm{mmol} / \mathrm{l}$ on day 2 ( $p<0.0001$ versus controls; unpaired t-test) and $2.27 \pm 0.18 \mathrm{mmol} / \mathrm{l}$, median $2.32 \mathrm{mmol} / \mathrm{l}$ on day 3 ( $p=0.05$ versus controls; unpaired t-test). The mean value of the pooled S-Ca in neonates with infection was 2.18 $\pm 0.24 \mathrm{mmol} / \mathrm{l}$, median $2.19 \mathrm{mmol} / \mathrm{l}(\mathrm{p}<0.0001$ versus controls; unpaired t-test).

The mean values of S-CRP were $24.63 \pm 29.58 \mathrm{mg} / \mathrm{l}$, $34.63 \pm 31.46 \mathrm{mg} / \mathrm{l}$, and $22.02 \pm 18.64 \mathrm{mg} / \mathrm{l}$ (normal $<5 \mathrm{mg} / \mathrm{l}$ ) on days 1,2 and 3 , respectively. The median values of S-CRP were $12.55 \mathrm{mmol} / \mathrm{l}, 23.65 \mathrm{mmol} / \mathrm{l}$ and $19.25 \mathrm{mmol} / \mathrm{l}$ on days 1,2 and 3 , respectively. The mean value of the pooled S-CRP in neonates with sepsis was $27.16 \pm 27.73 \mathrm{mg} / \mathrm{l}$; median $19.0 \mathrm{mg} / \mathrm{l}$.

The mean values of S-PCT were $20.85 \pm 23.30 \mu \mathrm{g} / 1$, $23.44 \pm 36.12 \mu \mathrm{g} / \mathrm{l}$ and $8.05 \pm 16.71 \mu \mathrm{g} / \mathrm{l}$ (normal < $0.5 \mu \mathrm{g} / \mathrm{l}$ ) on days 1, 2 and 3 , respectively. The median values of S-PCT were $7.12 \mu \mathrm{g} / \mathrm{l}, 6.0 \mu \mathrm{g} / \mathrm{l}$ and $2.77 \mu \mathrm{g} / \mathrm{l}$ on days 1,2 and 3 , respectively. The mean value of the pooled S-PCT in neonates with sepsis was $18.35 \pm 27.64 \mu \mathrm{g} / \mathrm{l}$; median $6.0 \mu \mathrm{g} / \mathrm{l}$.

There were no mutual correlations between S-Ca and S-CRP or S-PCT on days 1, 2 and 3. (Table 2).

We found weak inverse correlations with tendency to statistical significance between S-Ca and S-PCT ( $\mathrm{r}=-0.22$; $p=0.06)$, and S-Ca and S-CRP $(r=-0.19 ; p=0.09)$, respectively, once the data were pooled.

\section{DISCUSSION}

Our paper gives evidence about a transient drop in total serum calcium in the course of early-onset neonatal infection. Furthermore, we also found a tendency to slight inverse relationship between pooled total serum calcium levels and biochemical markers of inflammation (CRP and PCT), with tendency to statistical significance.

Regarding our patients, the relationship between S-PCT and S-Ca, in particular the hypocalcemic effect of PCT, was also considered $(8,9,17)$. The relationship between PCT and serum levels of calcium remains unclear and rather controversial, as there is no evidence of PCT binding to the calcitonin cellular receptors (18). In a study with healthy volunteers, infusion of calcium gluconate physiologically stimulated the release of mature calcitonin with only minimal effects on the S-PCT levels (19). Furthermore, septic patients with ionised hypocalcemia were reported as having low serum $25(\mathrm{OH})$ vitamin D levels which were inversely correlated with S-PCT (20). In another study in patients with septic shock, S-PCT levels were correlated with the severity of disease and S-CRP, but not with S-Ca ${ }^{2+}$ levels (21). In adult patients with sepsis, the low $\mathrm{S}-\mathrm{Ca}^{2+}$ concentrations were inversely related to S-PCT, TNF-alpha and IL-6 (17). Therefore, in patients with sepsis/infection, the combined hypocalcemic effect of PCT together with TNF-alpha, IL-1, IL-6, and aminoglycoside up-regulation of CaSR can not be ruled out $(10-15,17)$.

All our patients with early-onset neonatal infection received appropriate antibiotic treatment and the clinical course and outcome was favorable. None developed organ dysfunction. The S-Ca was not found to be a predictor of further changes in markers of inflammation, as there were no mutual correlations between S-Ca and S-CRP or S-PCT on days 1, 2 and 3, respectively (Table 2).

We are well aware of the limitations of our paper as $\mathrm{S}-\mathrm{Ca}^{2+}$, albumin-adjusted-Ca, serum levels of 25-OH-vitamin D, S-PTH, TNF-alpha, IL-1 and IL- 6 were not assessed, together with the fact that all three observed parameters (S-Ca, CRP, PCT) were not always measured in each obtained sample in the course of infection. Furthermore, we analysed only full-term neonates with early-onset infection and our results are probably not fully applicable to pre-term neonates.

In conclusion, total S-Ca was decreased in neonates with early-onset infection and did not show any strong or significant correlation with S-CRP and S-PCT, however, there was a tendency to inverse relationship with these parameters once the data were pooled. Pediatricians should be aware of the fact that low total S-Ca should alert their attention to the risk of neonatal infection/sepsis, and, likewise, that the children with neonatal infection/sepsis are at a higher risk of hypocalcemia with all its consequences.

\section{ACKNOWLEDGEMENTS}

This paper was presented as an abstract at the American Society for Bone and Mineral Research (ASBMR) meeting in Montreal, Canada, October 1, 2018.

\section{REFERENCES}

1. Kelly A, Levine MA. Hypocalcemia in the critically ill patient. J Intensive Care Med 2013; 28: 166-77

2. Cardenas-Rivero N, Chernow B, Stoiko MA, Nussbaum SR, Todres ID. Hypocalcemia in critically ill children. J Pediatr 1989; 114: 946-51.

3. Ahmad MS, Ahmad D, Medhat N, Zaidi SAH, Farooq H, Tabraiz SA. Electrolyte Abnormalities in Neonates with Probable and Culture-Proven Sepsis and its Association with Neonatal Mortality. J Coll Physicians Surg Pak 2018; 28: 206-9.

4. Dias CR, Leite HP, Nogueira PC, Brunow de Carvalho W.Ionized hypocalcemia is an early event and is associated with organ dysfunction in children admitted to the intensive care unit. J Crit Care 2013; 28: 810-5.

5. Sanchez GJ, Venkataraman PS, Pryor RW, Parker MK, Fry HD, Blick KE. Hypercalcitoninemia and hypocalcemia in acutely ill children: 
studies in serum calcium, blood ionized calcium, and calcium-regulating hormones. J Pediatr 1989; 114: 952-6.

6. Haghbin S, Serati Z, Sheibani N, Haghbin H, Karamifar H. Correlation of hypocalcemia with serum parathyroid hormone and calcitonin levels in pediatric intensive care unit. Indian J Pediatr 2015; 82: 217-20.

7. Kopelman AE. Metabolic problems in the newborns. Hypocalcemia. In: The Merck Manual 1992, Merck\&Co Inc: 2004-2005.

8. Steinwald PM, Whang KT, Becker KL, Snider RH, Nylen ES, White JC. Elevated calcitonin precursor levels are related to mortality in an animal model of sepsis. Crit Care 1999; 3: 11-6.

9. Müller B, Becker KL, Kränzlin M, Schächinger H, Huber PR, Nylèn ES et al. Disordered calcium homeostasis of sepsis: association with calcitonin precursors. Eur J Clin Invest 2000; 30: 823-31.

10. Hendy GN, Canaff L. Calcium-Sensing Receptor Gene: Regulation of Expression. Front Physiol 2016; 7: 394.

11. Hendy GN, Canaff L. Calcium-sensing receptor, proinflammatory cytokines and calcium homeostasis. Semin Cell Dev Biol 2016 Jan; 49: 37-43.

12. Jackson GL, Sendelbach DM, Stehel EK, Baum M, Manning MD, Engle WD. Association of hypocalcemia with a change in gentamicin administration in neonates. Pediatr Nephrol 2003; 18: 653-6.

13. Chiruvolu A, Engle WD, Sendelbach D, Manning MD, Jackson GL. Serum calcium values in term and late-preterm neonates receiving gentamicin. Pediatr Nephrol 2008; 23: 569-74.
14. McLarnon S, Holden D, Ward D, Jones M, Elliott A, Riccardi D. Aminoglycoside antibiotics induce $\mathrm{pH}$-sensitive activation of the calcium-sensing receptor. Biochem Biophys Res Commun 2002; 297: 71-7.

15. Ward DT, Maldonado-Pérez D, Hollins L, Riccardi D. Aminoglycosides induce acute cell signaling and chronic cell death in renal cells that express the calcium-sensing receptor. J Am Soc Nephrol 2005; 16: 1236-44.

16. Töllner U. Early diagnosis of septicemia in the newborn. Clinical studies and sepsis score. Eur J Pediatr 1982;138: 331-7.

17. Lind L, Carlstedt F, Rastad J et al. Hypocalcemia and parathyroid hormone secretion in critically ill patients. Crit Care Med 2000; 28: 93-9.

18. Maruna P, Nedelníková K, Gürlich R. Physiology and genetics of procalcitonin. Physiol Res 2000; 49(Suppl 1): S57-61.

19. Giovanella L. Serum procalcitonin and calcitonin normal values before and after calcium gluconate infusion. Exp Clin Endocrinol Diabetes 2012; 120: 169-70.

20. Chen Z, Luo Z, Zhao X et al. Association of vitamin D status of septic patients in intensive care units with altered procalcitonin levels and mortality. J Clin Endocrinol Metab 2015; 100: 516-23

21. Claeys R, Vinken S, Spapen H et al. Plasma procalcitonin and C-reactive protein in acute septic shock: clinical and biological correlates. Crit Care Med 2002; 30: 757-62. 